\title{
The Effect of the Arab Spring on the Performance of Islamic and Conventional Banks in Egypt: Which Model Performs Better Amidst Crisis?
}

\author{
Zar-Tashiya Khan ${ }^{1}$, Andres Ramirez ${ }^{1} \&$ David Ketcham ${ }^{1}$ \\ ${ }^{1}$ School of Business, Bryant University, Rhode Island, USA \\ Correspondence: Zar-Tashiya Khan, School of Business, Bryant University, Rhode Island, USA. E-mail: \\ zkhan1@bryant.edu
}

Received: April 7, 2020

Accepted: May 14, 2020

Online Published: July 7, 2020

doi:10.5430/ijfr.v11n4p180

URL: https://doi.org/10.5430/ijfr.v11n4p180

\begin{abstract}
This empirical study analyzes financial institutions and performance in times of external crisis and whether a difference in performance between Islamic (IBs) and conventional (CBs) bank models exists. Egypt surrounding the Arab Spring (2009-2013) is taken as a case study, comparing 6 CBs and 3 IBs. Financial ratio analysis is the main method employed, allowing performance to be measured by efficiency, capital adequacy, profitability, solvency, liquidity, and credit risk performance. Due to small sample size, the nonparametric Mann-Whitney U test and effect size analysis assess the significance of the ratio analysis results. Results show CBs have superior performance in all indicators other than Cost-Income and NIM. Efficiency performance for both models were equally volatile or alternately stable with progression through the crisis, while IBs increased capital adequacy and solvency during the crisis. IBs profitability was significantly negatively impacted by the crisis, other than related to NIM, while CBs increased profitability rates. IBs liquidity worsened, then improved midway through the crisis while CBs stabilized liquidity rates throughout. IBs improved credit risk midway through the crisis while CBs declined. Nonparametric results hold observed differences are insignificant and have weak effect size for all but the TENL ratio.
\end{abstract}

Keywords: financial crises, Islamic banks, Arab Spring, Egypt, performance evaluation, financial ratio analysis

\section{Introduction}

The purpose of this project is to look at how financial and political crises effects financial institutions like banks. I hope to in the end be able to assess how internally banks are able to handle external crises - based off their different foundational goals. This is significant, as prior to research I already know Islamic banks are intrinsically different from other or western banking systems in that they run through a profit-loss sharing system. And with this, I hope to learn the differences between Islamic and conventional banking regarding their services and products, and why these differences are relevant. The relevance or value of this project is to contribute to growing literature in the field evaluating the performance of banks amidst crisis while addressing the limits of past research.

There have been studies with comparable methodology and scope, though most focus on profitability, and do not look in depth at each variable of performance over the course of a crisis with the Arab Spring time period. Research looks at other metrics too, such as efficiency, and employ models and statistical analysis that cannot be applied to this sample and so this study attempts to branch off of past pursuits by applying a different methodology with the use of nonparametric statistics - while increasing my own understanding of this field of statistics in the process. Other studies look at only Islamic banks in multiple countries during a given time period, and so cannot take into account country specific conditions or the relationship to non-Islamic bank performance.

The worth of this project is to establish a true picture of the financial health or position of financial institutions amidst crises - by taking Egypt during the Arab Spring as a case study. Conclusions that can be drawn from such a project are important to not only depositors and shareholders, but to managers and regulators of both types of institutions - and can help drive key institutional decisions and policies made in response or anticipation to external crises. This is substantial as financial institutions play a key role in economies as they provide the necessary funds to drive growth and development.

In order to answer this question, financial ratio analysis is performed on the Egyptian financial statement data from 
FactSet to analyze the trends of each bank model relative to each other as well as across time. This will allow for discussion on the variation of the impact of the crisis on each internal determinant or variable of performance. The nonparametric test of rank order with the Mann-Whitney $U$ test is performed to determine the significance of the results obtained through the ratio analysis and whether they can be generalized for these two population samples. The study ends with a discussion of the implications of our results from both parts of the analysis.

\section{Literature Review}

In today's financially global environment, it is nearly impossible to work without encountering other manners of banking, and it is just as important when evaluating one's own system and bank model to remain innovative as well as concurrent to whatever issues may press one's own organization and larger economy. In this comes the importance in understanding the backgrounds and principles of both bank models evaluated in this research paper, as well as to establish the connection and relevance of the effects of external crisis on these differing banking structures. Already there have been various studies done in the realm of Islamic finance that either explore the significance of a wide range of internal and external variables on bank performance or focus in on certain indicators of financial ratio analysis like profitability - and both were looked at in order to complete this unique research project.

Without looking too deep into his theological presentation behind Islamic banking's foundation, Hassan (2007) is still able to present a great compilation of the key operating differences that Islamic banks equip against competing non-Islamic financial institutions. He summarizes Islamic banks rely on a combination of three key principles; sharing, leasing, and sale - which is how funds have to essentially be channeled through. In contrast, the financial transactions and profit of conventional banks are built on interest and the debtor-lender relationship. Islamic institutions also share an extra layer of corporate governance with Sharia boards to monitor their religious adherence. This is since they face strict rules, such as the prohibition of riba or interest in all transactions, prohibition of gharar or speculation in activities, the payment of zhakat - which can be seen as a social welfare or wealth redistribution payment banks have a duty to payout, and lastly all business and investments must be in those activities deemed halal or in line with Islamic principles - excluding anything to do with gambling, alcohol, etc.

Visser's (2013) discussion accompanies Hassan's and explains how these principles form the unique balance sheet or assets and liabilities of an Islamic bank - though each individual bank is evidently open to its own goals as well as the laws of its country, plus the increasing need to interact with other interest-based banks. This brings in a list of financial instruments that are supposed to be built on the idea of either profit-sharing or profit-and-loss sharing (PLS). This is since it is important to note, in the Quran riba is clearly frowned up, but profit itself is not. Likewise, Lewis (2010) clarifies mudaraba and musharaka are the two most preferred PLS forms used by banks to raise funds. Mudaraba is a silent contract where one party is the financier who entrusts funds to the other party, who undertakes management of it and the venture. The entrepreneur becomes a trustee who returns the principal plus a pre-agreed profit while keeping the leftovers for himself. Thus, the financier is the one who bares the liability for losses, though it is limited to their own contribution. Musharaka is an equity partnership or joint venture contract where instead all parties have the right to management. Profits are pre-agreed and losses are shared too, based on contributions - and this type of contract is known for financing commercial enterprises, real estate development, or rural finance.

Non-PLS instruments include the popular murabaha or cost-plus contract, ijara which is rent or lease that still contains an allowable profit component, and types of loans where in place of interest a commission is charged. Sukuk is also a type of bond that cannot represent a debt as conventional bonds may, so it is instead obtained through the securitization of an asset. Aside from these there are many other even more complex instruments Islamic institutions may employ. With this, before his study, Fayed (2013) also explains Islamic banks maintain three types of deposit accounts; current, savings, and investment - with the latter two showing differences from conventional banks. Savings deposits vary and may involve a full guarantee, with no profit promised, while others are more like investments that banks use to invest in fairly risk-free and short-term projects. Investment deposits meanwhile are for a fixed or unlimited time period where profits or losses are expected to be shared in a given proportion with the bank. Capital isn't guaranteed, though banks equip several methods to acquire assets or financing projects that can be broadly categorized into three areas; investment, trade and lending.

Fayed's performance study continues on to compare Islamic and conventional banking in Egypt between 2008 to 2010, employing financial ratio analysis to gauge profitability, liquidity, credit risk, and solvency using the Bank-o-meter model. His project provides useful context for my own research, as his results indicate the superiority of conventional banks over Islamic ones in all ratio criteria - though he includes no further statistical analysis into these figures. With similar objective but more statistical testing, El Massah and Al-Sayed (2015) focus on the UAE and found differences in performance indicators are statistically significant. Islamic banks were on average less solvent, less profitable, more 
liquid, and yet had higher credit risk - matching Fayed's findings. Another comparable study by Elsiefy (2013) looked at Qatar, while including growth rates, market shares, and such trends in its analysis of the ratios too in its attempt to also address whether Islamic banks are able to showcase sustainable growth amidst financial crisis. Looking at data pre and post the financial crisis, he found Islamic banks maintain stronger total assets, credit, and deposits growth rates but less sustainable profitability rates over conventional banks in these periods. His asset quality and risk ratios exhibit Islamic banks sustain lower nonperforming loans and are less leveraged too. He also interestingly found they were more efficient in utilizing assets and less liquid, which is inconsistent with the accepted view Islamic banks are excessively liquid.

Aside from comparative performance studies, the other type of study consulted for this project includes those that employ their own linear regression models and extensively focus on establishing a relationship between a number of variables to profitability as the dependent. These involve complex statistical analysis but using Hassan and Bashir's (2005) study on the determinants of profitability I attempted to understand these studies. Using their regression model and bank level data, they established a relationship between bank characteristics and a financial environment on the performance of Islamic banks. They came up with determinants of Islamic bank profitability while controlling for the macroenvironment, financial market structure, and taxation - including high capital and loan-to-asset ratios. They also asserted taxes negatively affect bank performance while fortunate macro conditions give positive performance. They also discovered profitability and overhead have a strong positive correlation.

Yahya, Akhtar, and Tabash (2017) studied the effect of political instability and other macroeconomic factors on the profitability of Islamic banks in Yemen surrounding the Arab uprising. They likewise developed two of their own models for profitability with nine independent variables and ROA and ROE as dependents. Their statistical and regression results hold operating efficiency and financial risk have significant negative relationships with profitability, while capital adequacy exhibits an insignificant negative relationship. Onwards, assets size, assets management, liquidity, deposits, GDP, inflation, and political instability have a significant positive impact on ROA and ROE. A similar empirical study on Qatari banks by Ibrahim (2016) employed descriptive statistics, a t-test on each variable, and correlation and regression analyses like most other studies aforesaid. He found ROA, liquidity, and capital adequacy values are higher for Islamic banks - while bank size is greater with conventional. And his regression held bank size and liquidity are significant in affecting profitability for both bank models. A comparable study with parallel results done by Almanaseer (2014) took the same idea and applied it to multiple countries and a period of financial crisis, looking to the GCC during the 2005 to 2012. However, he found the financial crisis did not have a significant impact on Islamic banks profitability. He further found increasing owners' equity decreased the impact of the financial crisis on profitability - while the impact of the financial crisis itself on profitability increased with likewise increasing total assets, liquidity, and overhead expenses. I also enjoyed the detailedness of the discussion of his hypotheses and results, which I may adapt.

My research next took me to nonparametric statistics, due to the nature of the small bank population of 9 in total available through FactSet. Nonparametrics are used in times when regular parametric statistics are not applicable or cannot be assumed, where Corder and Foreman (2014) summate parametric samples as those that may be randomly drawn from a normally distributed population, consist of independent observations except for paired values, consist of values on an interval or ratio measurement scale, have respective populations of approximately equal variances, approximately resemble a normal distribution, or are adequately large - as prior researchers Pett (1997) and Salkind (2004) held most researchers suggest $n>30$ while Warner (2008) pushed for consideration of $n>20$ as a minimum and $\mathrm{n}>10$ by group as a minimum. This led me to consider the Mann-Whitney $\mathrm{U}$ test, as it is the nonparametric equivalent of the t-test for independent samples. This test involves combining and rank ordering the data to determine if the values are randomly mixed or if they cluster at opposite ends. A random rank ordered signifies the two samples are not different, while clusters of one sample's values would indicate a difference.

Based off this, a Mann-Whitney U-test statistic for each of the two samples can be computed as;

$$
U_{i}=n_{1} n_{2}+\frac{n_{i}\left(n_{i}+1\right)}{2}-\sum R_{i}
$$

where $U_{i}$ is the test statistic for the sample of interest, $n_{i}$ is the number of values from the sample of interest, $n_{1}$ is the number of values from the first sample, $\mathrm{n}_{2}$ is the number of values from the second sample, and $\sum R \mathrm{i}$ is the sum of the ranks from the sample of interest. The lesser of the two computed values for $U_{l}$ and $U_{2}$ is chosen as the obtained value, $U$. Using this, the statistics can then be tested for significance by using a table of critical values given the sample sizes and a chosen level of risk or significance, known as $\alpha$ or alpha. This determines if the null and alternative hypotheses may be rejected, where the null hypothesis typically states the two samples are identical or have no significant 
difference in ranks while the alternative states the opposite. If the obtained value or $U$ is more than or equal to the critical value or $C V$ the null hypothesis must not be rejected, whereas if it is less than the critical value it is be rejected.

Following this, further analysis can be conducted to identify the strength of the treatment, or the degree of association between the samples, with effect size computed as;

$$
E S=\frac{|Z|}{\sqrt{n}}
$$

where $E S$ varies from 0 to $1,|Z|$ signifies the absolute value of the z-score, and $n$ the total number of observations. A value of .1 is thus identified as small or a weak association, .3 as medium or moderate, and .5 as large or a strong association according to Cohen (1988).

The formulas for finding the mean, standard deviation, and the z-score are further specified within the parameters of effect size analysis, with;

$$
\bar{x}=\frac{n_{1} n_{2}}{2}
$$

where $\bar{x}$ is the mean, and $n_{1}$ is the number of values from the first sample and $n_{2}$ the number of values from the second sample.

Standard deviation represented as $s$ is calculated as,

$$
s=\sqrt{\frac{n_{1} n_{2}\left(n_{1}+n_{2}+1\right)}{12}}
$$

and the z-score represented as $z^{*}$ is calculated as,

$$
z^{*}=\frac{U_{i}-\bar{x}}{s}
$$

with $U_{i}$ representing the $U$ statistic from the sample of interest.

\section{Research Design}

\subsection{Research Question}

The research question is as follows; "Is there a difference in the performance of conventional and Islamic banks in times of crises?" which will be answered by looking at a sample of banks focused on the Arab Spring time period in Egypt.

Definitions of key terms include...

- Performance refers to the comparative results of each bank's ratios which serve as performance indicators (for efficiency, capital adequacy, profitability, solvency, liquidity, and credit risk)

- Islamic banks are those that employ "a banking system that is based on the principles of Islamic or Sharia law and guided by Islamic economics. Two fundamental principles of Islamic banking are the sharing of profit and loss, and the prohibition of the collection and payment of interest by lenders and investors" (Lim, 2019)

- whereas Conventional banks for the purpose of this project are those that offer more than just Islamic or shariah compliant products, and are instead based off the debtor-creditor relationship and make profits off charging interest

- Crisis refers to the chosen Arab Spring event, as representative of a crucial time of instability that branches out with significant effects on a state's economic, political and other given affairs

- Arab Spring as "a series of antigovernment uprisings affecting Arab countries of North Africa and the Middle East beginning in 2010" until about 2012 for the purposes of this paper (Arab Spring)

- Egypt means only looking at a data sample focused in this country alone

The main objectives for this project are:

1) To look at the differences in performance for each bank model across time

2) To look at the differences in performance across institutional types (conventional versus Islamic) 
3) To examine the variation of the impact of the crisis on each internal determinant (variable) of performance - using ratio and other non-parametric statistical analysis

Since time is of importance to evaluating the effect of the progression through and after the crises on bank performance, and to see the difference of the crises period to before and after, 5 years of financial data are split into 3 approximated categories according to historical events while pin-pointing the onset of the crises towards the end of 2009; Before Arab Spring (2009), During Arab Spring (2010-2012), and After Arab Spring (2013).

This will allow me to frame a picture of the effect of the Arab Spring on these differing banks and bank models over time, and pinpoint when and where each may have performed better or worse regarding the different performance indicators against time. In the end, the goal is for the analysis of the trends and significance in the disparities between ratios and banks to lead into my conclusions on this data sample and the overall topic of this research.

\subsection{Research Methodology}

Foremost, this project involves Financial Ratio Analysis of the performance indicators using historical financial statement data, including income statements and balance sheets. Financial ratios are beneficial in permitting mathematical comparisons of financial statement line items as both small and larger businesses are represented proportionally. The relationships between these statements and ratios allows one to compare different companies in given industries, as well as prove useful to illustrating the financial standing and performance of a business. There are many advantages to ratio analysis, including how they simplify financial statements, facilitate inter-firm comparisons, and can have a part in investment or planning decisions. The bank data for this analysis has been obtained from primary data available in the FactSet database. The results of the ratio analysis are to be summated graphically to better visualize relative trends between bank models.

Tests as said under objective 3 are planned to be performed. Due to the sample size, this will require non-parametric statistical analysis as normality in the sample cannot be assumed. The non-parametric tests used in this study are a rank order test, specifically the Mann-Whitney $U$ test since the two samples (Islamic and conventional banks) are independent, and Effect Size Analysis as explained in the literature review. Lastly a Descriptive Statistics Summary of mean, standard deviation, and skewness to compare and analyze the performance of Islamic and conventional banks is included. This provides simple summaries about the sample and the measures in a manageable form.

This approach and methodology are appropriate for the frame and discipline of this project based off the extensive review of literature, where many other studies use a compilation of these methods and tests. This methodology and scope will also again allow me to differentiate my work from past work in this field to answer my unique question and small sample with the addition of nonparametric tests. With this, it is also important that I realize my own grasp of statistics and finance up to this point, and so cannot perform as complex tests as other professionals or published fellows in this field may - but am still open to being able to learn and perform a number of statistical analysis as aforementioned in my attempt to complete this project.

\subsection{Data Sample}

The data sample available in FactSet of 3 Islamic and 6 Conventional Banks covering the necessary years in Egypt are identified below, purposely excluding those banks specialized in certain areas of finance while understanding all the banks included have varying asset sizes.

Table 1. Data sample

\begin{tabular}{cc}
\hline Islamic Banks & Conventional Banks \\
\hline Faisal Islamic Bank of Egypt & Bank of Alexandria \\
\hline Al Baraka Bank Egypt & Al Ahli Bank of Kuwait-Egypt \\
\hline Abu Dhabi Islamic Bank-Egypt & Commercial International Bank-Egypt \\
\hline & Qatar National Bank Al-Ahli \\
\hline
\end{tabular}




\subsection{Performance Indicators \& Financial Ratios Employed in Study}

Table 2. Performance indicators and ratios employed in study

\begin{tabular}{|c|c|c|}
\hline $\begin{array}{c}\text { Performance } \\
\text { Indicator }\end{array}$ & Ratio & Calculation \\
\hline \multirow{4}{*}{ Efficiency } & Cost-Income & Operating or Non - Interest Expense \\
\hline & Ratio & Operating Income \\
\hline & Operating & Total Operating or Non - Interest Expense \\
\hline & Efficiency & Total Assets \\
\hline \multirow{2}{*}{$\begin{array}{c}\text { Capital } \\
\text { Adequacy }\end{array}$} & Capital Adequacy & Total Common Equity - Intangible Assets \\
\hline & Ratio (CAR) & Total Assets - Intangible Assets \\
\hline
\end{tabular}

Measures a bank's costs relative to income and spending relative to revenue generation. Lower ratios signify higher efficiency and cost management and profitability.

Measures the effectiveness of management in keeping costs low while generating revenues. Lower ratios signify higher operational efficiency.

Measures a bank's available capital relative to their risk-weighted assets or credit exposures, and their ability to absorb losses in times of financial shock or downturn. Higher ratios signify greater capital adequacy and stability and lower risk.

Measures the effectiveness of management in generating profits off Return on Assets Net Income its available assets. Higher ratios (ROA) $\overline{\text { Total Assets }}$ signify higher profitability.

Measures the effectiveness of

\section{Profitability}

\section{Return on Equity (ROE)}

\section{$\frac{\text { Net Income }}{\text { Shareholder Equity }}$} management in using equity or net assets to earn profits. Higher ratios signify higher profitability.

Measures net income or profit to generated revenues, and how much

$\begin{array}{ll}\text { Net Profit Margin } & \frac{\text { Net Income }}{\text { Revenue }} \\ \text { (NPM) } & \end{array}$

Net Interest Margin (NIM)

$\frac{\text { Interest Income - Interest Expense }}{\text { Avg.Earning Assets or Invested Assets }}$
each dollar of revenue translates into profit. Higher ratios signify higher profitability.

Measures the difference between interest income generated by the banks and the amount paid out to depositors in relation to their investments. Higher ratios signify higher profitability. 
Measures a firm's financial leverage and the degree of their financing through debt rather than self-owned funds. Also reflects the ability of

Solvency Debt-to-Equity

Total Loans

$\overline{\text { Total Assets }}$

Liquidity

Loans-to-Deposits

$\frac{\text { Total Loans }}{\text { Total Deposits }}$ shareholder equity to cover

outstanding debts in times of financial

shock or downturn. Too high ratios suggest a firm cannot generate enough cash to satisfy debt obligation, but too low suggest a firm is not taking advantage of increased profits. Lower ratios are considered less risky.

Measures how much total assets is tied up in loans for a bank. Higher ratios signify lower liquidity and higher risk.

Measures a bank's ability to cover loan losses and withdrawals from customers. Too high ratios suggest a firm is not liquid enough to cover unforeseen needs for funds, but too low suggest a firm is not earning optimally. Higher ratios signify lower liquidity and higher risk.

Measures a bank's ability for equity to cover loan losses, as in times of financial shock or downturn. Higher ratios signify lower credit risk.

\subsection{Hypotheses}

My hypotheses delve into my predictions (and some explanations for these) for each core variable or performance indicator category underneath the measurement of performance, as well as relative to the progression of time with the external crisis event, and for the nonparametric test to see whether we can accept the results of the ratio analysis as follows;

\subsubsection{Ratio Analysis Hypotheses}

$\mathrm{H}_{1}$ : There are no significant differences in efficiency performance (Cost-Income Ratio \& Operating Efficiency) between both bank models. $\mathrm{H}_{2}$ : There is a negative relationship between efficiency and the external crisis for both bank models.

$\mathrm{H}_{3}$ : Conventional banks lead in capital adequacy (CAR).

$\mathrm{H}_{4}$ : There is a negative relationship between capital adequacy and the external crisis; this negative relationship is stronger or more apparent in conventional banks.

- Presuming the effect of capital flight, etc. hits conventional banks harder

$\mathrm{H}_{5}$ : Conventional banks lead in all profitability indicators (ROA, ROE, NPM, NIM). 
$\mathrm{H}_{6}$ : There is a negative relationship between profitability and the external crisis; this negative relationship is stronger or more apparent in conventional banks.

- Presuming conventional banks are more concerned with achieving profits than Islamic banks.

- Considering the positive relationship between profitability and risk.

$\mathrm{H}_{7}$ : Islamic banks lead in solvency (Debt-to-Equity).

$\mathrm{H}_{8}$ : There is a negative relationship between solvency and the external crisis; this negative relationship is stronger or more apparent in conventional banks.

- Under presumption conventional banks have higher debt in general.

$\mathrm{H}_{9}$ Islamic banks lead in all liquidity indicators (Loan-to-Assets \& Loan-to-Deposits).

$\mathrm{H}_{10}$ : There is a positive relationship between liquidity and the external crisis; this positive relationship is stronger or more apparent in Islamic banks.

- Under presumption Islamic banks are already more liquid before the crisis and only increase this throughout the crisis.

$\mathrm{H}_{11}$ : Conventional banks lead in credit risk (Total Equity to Net Loans).

$\mathrm{H}_{12}$ : There is a positive relationship between credit risk and the external crisis; this positive relationship is stronger or more apparent in conventional banks.

- Under presumption conventional banks utilize more debt-financing while Islamic banking relies more on asset-backed securities and equity participation.

\subsubsection{Mann-Whitney U Test Hypotheses}

$\mathrm{H}_{\mathrm{O}}$ : The two populations are identical, or there is no tendency of ranks of one method to be higher or lower than the other.

$\mathrm{H}_{\mathrm{A}}$ : The two populations are not identical, or there is a tendency of ranks of one method to be systematically higher or lower than the other.

\section{Results}

\subsection{Financial Ratio Graphs}

Figures 1-11 below illustrate trends between Conventional and Islamic Bank ratio results, with visible differences between bank models across time in many cases.

\subsubsection{Efficiency}

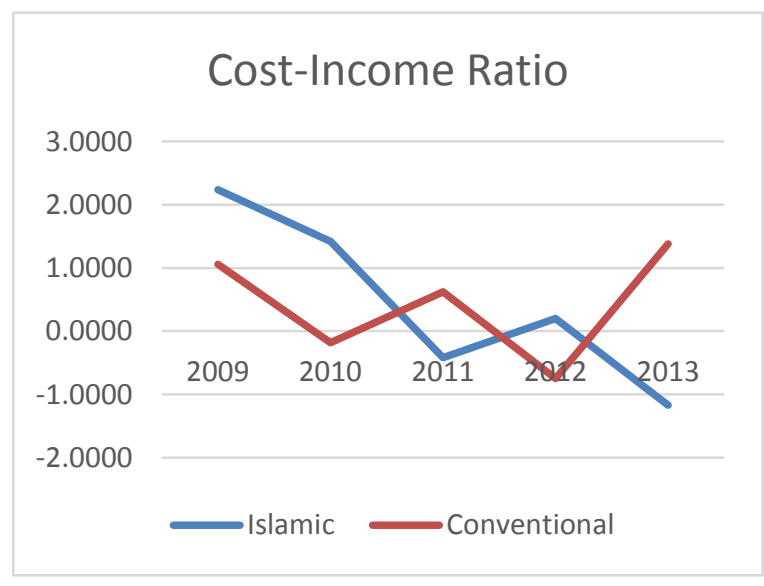

Figure 1. Cost-income ratio

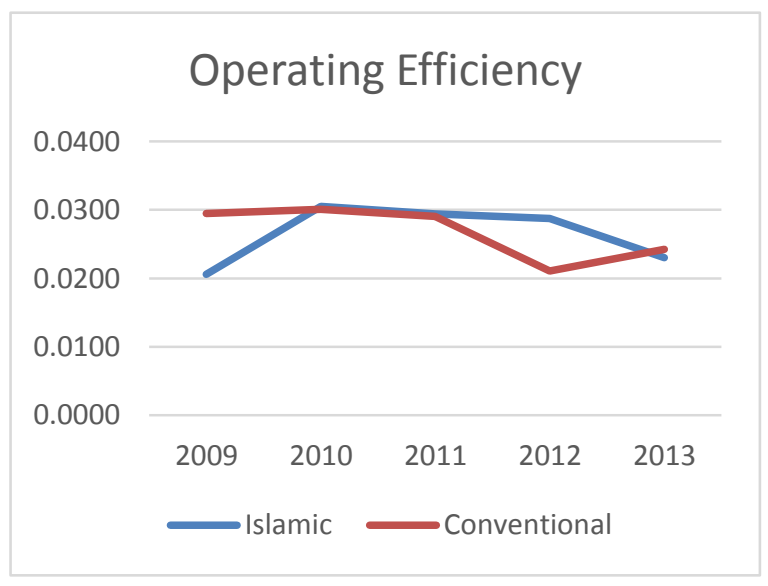

Figure 2. Operating efficiency ratio 


\subsubsection{Capital Adequacy}

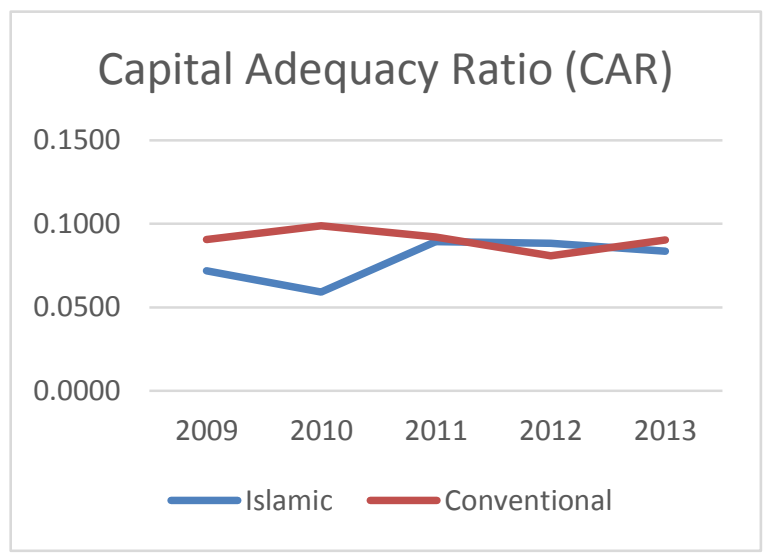

Figure 3. Capital adequacy ratio

\subsubsection{Profitability}

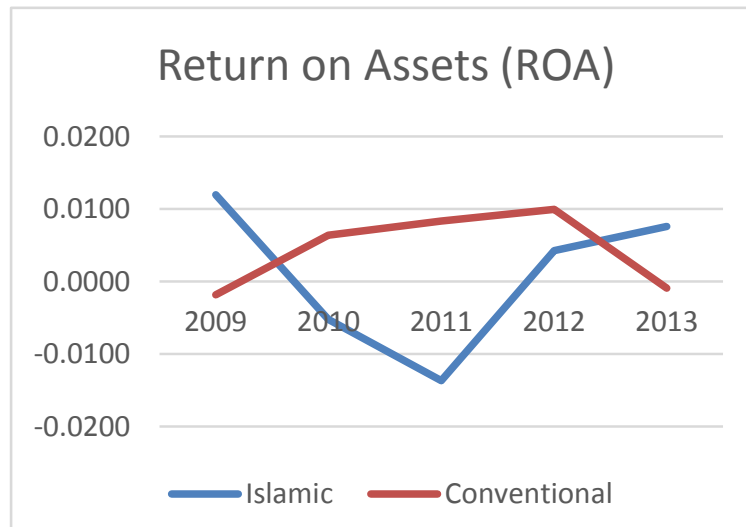

Figure 4. Return on assets ratio

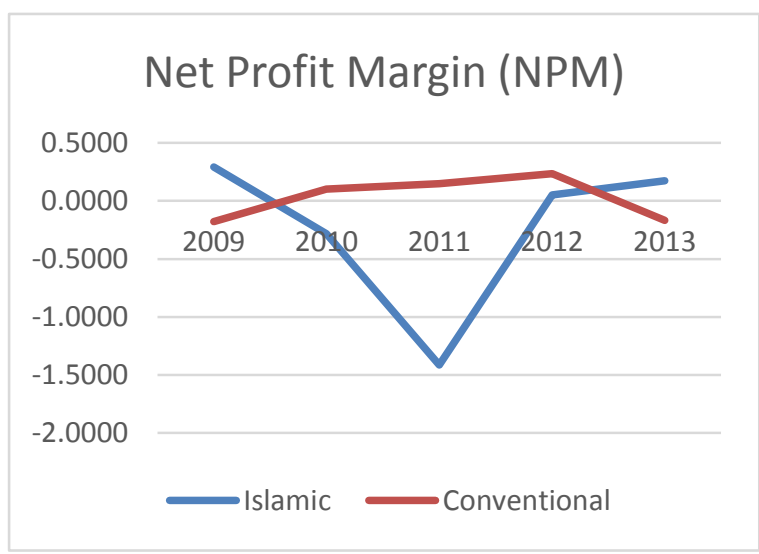

Figure 6. Net profit margin ratio

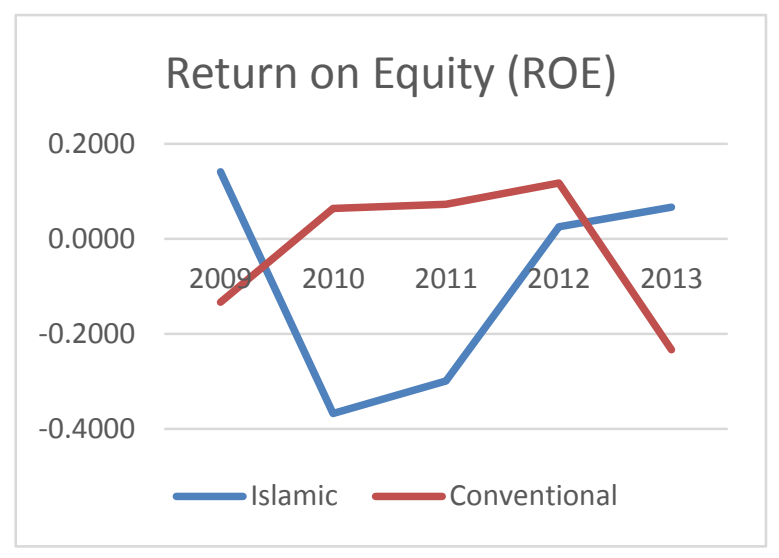

Figure 5. Return on equity ratio

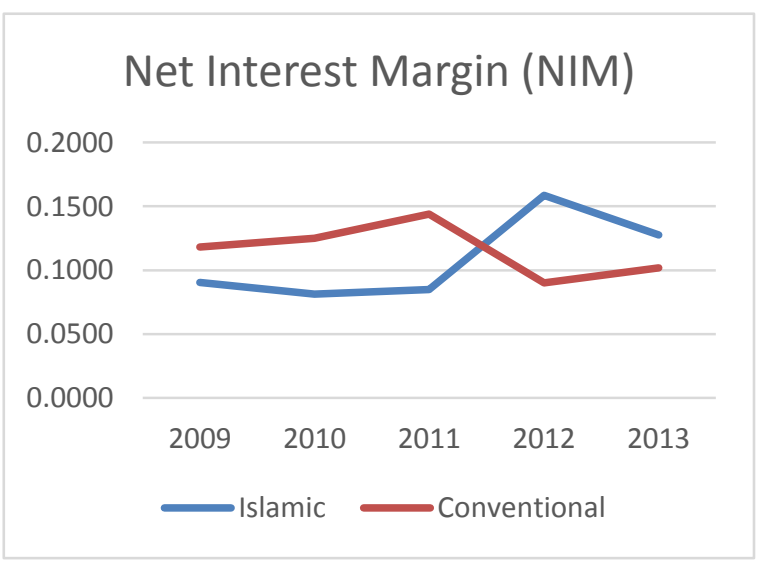

Figure 7. Net interest margin ratio 


\subsubsection{Solvency}

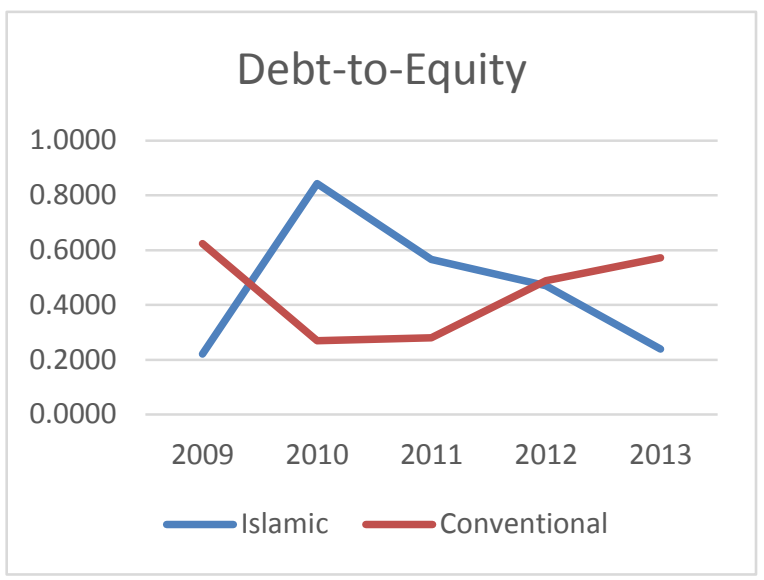

Figure 8. Debt-to-equity ratio

\subsubsection{Liquidity}

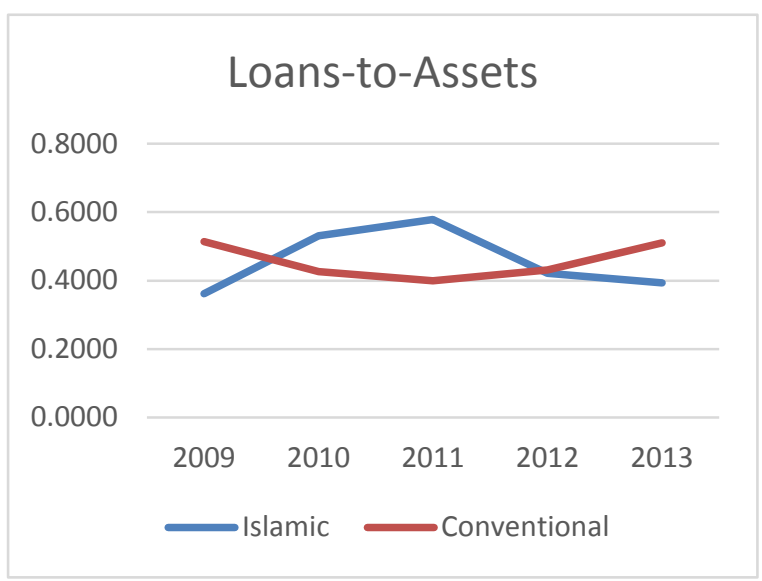

Figure 9. Loans-to-assets ratio

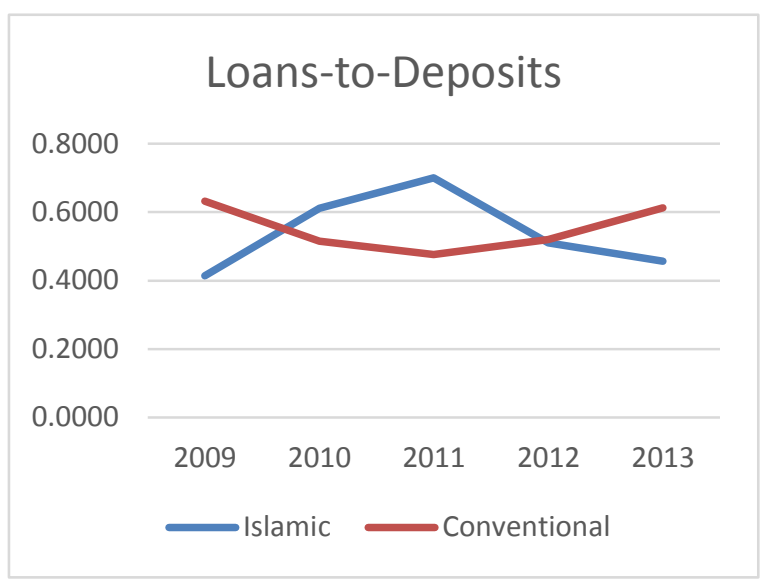

Figure 10. Loans-to-deposits ratio

\subsubsection{Credit Risk}

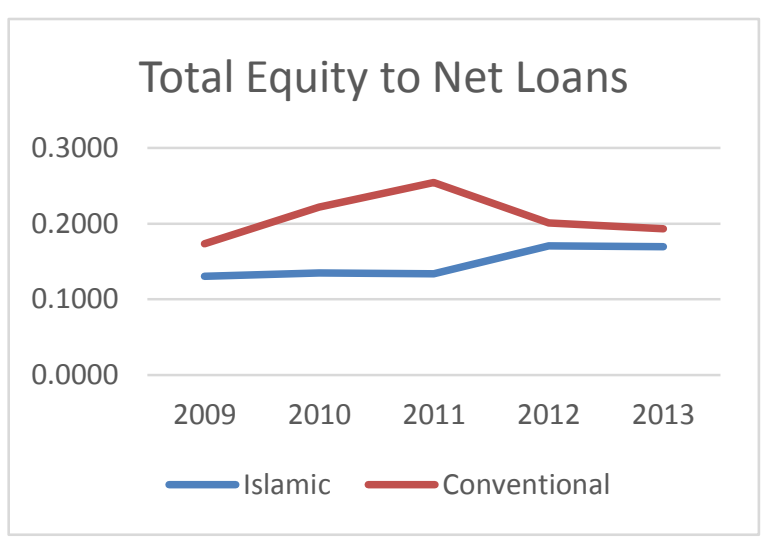

Figure 11 . Total equity to net loans ratio 


\subsection{Mann-Whitney U-Test Results}

The rank tests for 'All Years' resulted in the U-statistic being greater than the critical value of 143, as identified in Appendix A due to rank samples or $n$ of 15 and 30 and a chosen $\alpha$ of .05, except in the case of the last ratio of Total Equity to Net Loans (TENL) where the U-statistic was less than the critical value. This means all ratios aside from TENL result in acceptance of the null hypothesis $\left(\mathrm{H}_{\mathrm{O}}\right)$ and rejection of the alternative hypothesis $\left(\mathrm{H}_{\mathrm{A}}\right)$ - declaring both samples ratios tend to not be systematically higher or lower than one another with $95 \%$ confidence $(\alpha=.05)$. This in effect discredits the ability to normalize the differences in performance shown in Figures 1-10 for these two bank population samples in Egypt. The rank tests for 'Year by Year' were included to show the spread of the U-values across all 5 years, held against a smaller critical value of 1 due to $n$ of 3 and 6 as shown in Appendix A. This reveals variance across the 5 years, with a U-value arising in both the Loan to Assets and Loan to Deposits ratios being less than the critical value and thus rejecting the null hypothesis.

\subsection{Effect Size Results}

Results of the effect size analysis, follow those of the Mann Whitney U-test as looking at 'All Years' indicates all ratios other than for TENL resulted in a weak degree of association or strength, or small effect size between both sample groups, whereas TENL resulted in a moderate strength or medium effect size. This in consequence states that there is a weak significance of the results or differences observed between both groups ratio performance. The results for 'Year by Year' were again included to point out observed variance in the effect size from weak to moderate and even sometimes strong across the 5-year periods. Moreover, these identified strong points when matched up to the financial ratio graphs are frequently at points of the graph when both sample groups move in opposite or parallel directions to each other rather than in convergence. Herein these results may also be affected by the short time span and sample looked at in this study.

\subsection{Descriptive Statistics Summary}

Table 3. Descriptive statistics summary

\begin{tabular}{|c|c|c|c|c|c|c|c|c|c|}
\hline \multirow[t]{2}{*}{$\begin{array}{l}\text { Performance } \\
\text { Indicator }\end{array}$} & \multirow[t]{2}{*}{ Ratio } & \multicolumn{4}{|c|}{$\begin{array}{l}\text { Standard } \\
\text { Deviation }\end{array}$} & \multicolumn{2}{|c|}{ Minimum } & \multicolumn{2}{|c|}{ Maximum } \\
\hline & & Islamic & Conv & Islamic & Conv & Islamic & Conv & Islamic & Conv \\
\hline \multicolumn{10}{|c|}{ \# Observations } \\
\hline & & 15 & 30 & 15 & 30 & 15 & 30 & 15 & 30 \\
\hline \multirow{2}{*}{ Efficiency } & Cost-Income & 0.4535 & 0.4239 & 2.2697 & 3.8643 & -4.5699 & -9.6947 & 4.7088 & 12.7519 \\
\hline & Op Efficiency & 0.0265 & 0.0268 & 0.0121 & 0.0120 & 0.0070 & 0.0095 & 0.0510 & 0.0604 \\
\hline $\begin{array}{c}\text { Capital Adequacy } \\
\text { Ratio }\end{array}$ & CAR & 0.0785 & 0.0905 & 0.0272 & 0.0289 & 0.0291 & 0.0307 & 0.1237 & 0.1260 \\
\hline \multirow{4}{*}{ Profitability } & ROA & 0.0010 & 0.0044 & 0.0225 & 0.0197 & -0.0458 & -0.0605 & 0.0266 & 0.0264 \\
\hline & ROE & -0.0868 & -0.0224 & 0.4751 & 0.4365 & -1.3974 & -1.9201 & 0.2340 & 0.2514 \\
\hline & NPM & -0.2360 & 0.0281 & 1.2234 & 0.5789 & -4.2190 & 0.5013 & 0.4956 & 0.5013 \\
\hline & NIM & 0.1086 & 0.1158 & 0.0594 & 0.0554 & 0.0253 & 0.0396 & 0.2274 & 0.3025 \\
\hline Solvency & Debt-to-Equity & 0.4683 & 0.4472 & 0.4469 & 0.4121 & 0.0201 & 0.0497 & 1.4164 & 1.4308 \\
\hline \multirow{2}{*}{ Liquidity } & Loans-to-Assets & 0.4570 & 0.4562 & 0.1403 & 0.1352 & 0.1635 & 0.1212 & 0.6384 & 0.6607 \\
\hline & Loans-to-Deposits & 0.5384 & 0.5511 & 0.1725 & 0.1687 & 0.1797 & 0.1378 & 0.7267 & 0.7837 \\
\hline Credit Risk & TENL & 0.1478 & 0.2088 & 0.0606 & 0.0923 & 0.0662 & 0.0734 & 0.2676 & 0.5252 \\
\hline
\end{tabular}

Table 3 offers a statistical summary for each sample's ratios, allowing for side to side comparison of mean, standard deviation, minimum and maximum values. 


\section{Discussion}

Withstanding the nonparametric tests disability to generalize or make significant these two samples results, a discussion of the visible trends across these bank samples and time period within the realm of this specific population sample study is relevant towards our understanding of Islamic and Conventional banks operations and performance amidst crises. As shown in Figures 4-6 and 8-10, key points of intersection exist at least 1 to 2 times over the course of the short 5 year period examined for most ratios - especially in 2010 and 2012, which are critical periods around the onset and easing of the crises event that appear to denote moments of recovery or re-balancing in the trends. On the other hand, Figure 11 for TENL suggests the two samples start to converge following 2013 - presumably in a shared effort by both banks to re-stabilize credit risks post-crises.

Further discussion of the financial ratio results relative to the proposed hypotheses are as follows;

$H_{1}$ : There are no significant differences in efficiency performance (Cost-Income Ratio \& Operating Efficiency) between both bank models.

$\mathrm{H}_{1}$ is rejected regarding the Cost to Income ratio based off Figure 1, where both sample groups continuously move inversely to one another, whereas based off Figure $2 \mathrm{H}_{1}$ is accepted for the Operating Efficiency ratio. Figure 1's rather high volatility suggests both bank models struggled with managing costs and profits, notably in their ability to generate revenues which for many fiscal years during the Arab Spring were reported negative. There is less variability between Islamic and conventional banks performance in Figure 2, where they converge throughout 2010-2011 while conventional banks were able to increase operating efficiency 2011 and after showing further careful management of costs.

\section{$\mathrm{H}_{2}$ : There is a negative relationship between efficiency and the external crisis for both bank models.}

$\mathrm{H}_{2}$ is accepted regarding the Cost to Income ratio as shown in Figure 1, where for both bank models this efficiency performance declined and became rather volatile over the course of the Arab Spring. $\mathrm{H}_{2}$ is meanwhile rejected for Operating Efficiency as shown in Figure 2, Islamic banks efficiency performance was little effected over the course of the Arab Spring whereas conventional banks saw a decrease and thus higher operational efficiency 2011-2013.

\section{$H_{3}$ : Conventional banks lead in capital adequacy (CAR).}

$\mathrm{H}_{3}$ is accepted based off Figure 3 as well as Figure 12 since overall conventional banks tended to lead in terms of CAR, with their mean and minimum values being consistently higher than those of the Islamic bank group. This reveals conventional banks generally have higher levels of capital available to them as in terms of common equity, which allows them to better absorb shock and lessen risk, while Islamic banks were able to increase CAR during the course of the crisis.

$H_{4}:$ There is a negative relationship between capital adequacy and the external crisis; this negative relationship is stronger or more apparent in conventional banks.

$\mathrm{H}_{4}$ is rejected as unlike expected in Figure 3, the crises event had a positive effect on CAR for Islamic banks while performance did drop minimally for conventional banks. This may be contributed by earlier presumptions on the effect of capital flight hitting conventional banks harder and ability to retain capital relative to assets, showing conventional banks are strained more in meeting financial obligations during the Arab Spring in terms of this stability measure.

\section{$H_{5}$ : Conventional banks lead in all profitability indicators (ROA, ROE, NPM, NIM).}

$\mathrm{H}_{5}$ is accepted for all profitability ratios other than NIM, as shown in Figure 7 conventional banks were negatively affected midway through the crises period. This is contributed by a decreasing amount of income or revenue generated off increasing assets and equity for the overall Islamic bank group. This shows that even with profit-loss-sharing instruments implemented, Islamic banks faced substantial losses during the crises period - which falls in line with lower profitability's reported in past studies (Fayed, 2013; Elsiefy 2013). Conversely, the Islamic banks increase in NIM performance during the course of the crises rejects $\mathrm{H}_{5}$ as Islamic banks as a group were able to generate increasing interest income with amounts of earning assets in face of the crisis while conventional banks were unable to.

$H_{6}:$ There is a negative relationship between profitability and the external crisis; this negative relationship is stronger or more apparent in conventional banks.

$\mathrm{H}_{6}$ is rejected as all profitability ratios other than NIM show a stronger negative relationship between the crises and profitability in the Islamic group. Figures 4-6 show Islamic banks were significantly negatively impacted by the Arab Spring, with drops in ROA, ROE, and NPM performance in 2010 to 2011 while conventional banks were able to stabilize profitability performance during the crises period. 


\section{$\mathrm{H}_{7}$ : Islamic banks lead in solvency (Debt-to-Equity).}

$\mathrm{H}_{7}$ is rejected as Figure 8 shows conventional banks had less volatile and lower Debt-to-Equity performance over the total sample study's period, whereas Islamic banks faced larger debt obligations with higher risk that significantly increased solvency performance nearing the crisis period - and then dropped following it.

$H_{8}$ : There is a negative relationship between solvency and the external crisis; this negative relationship is stronger or more apparent in conventional banks.

$\mathrm{H}_{8}$ is rejected as again conventional banks were able to lead in solvency performance withstanding the crisis period, while the negative relationship between the crisis and solvency is more apparent in the Islamic bank group's higher Debt-to-Equity performance.

\section{$\mathrm{H}_{9}$ Islamic banks lead in all liquidity indicators (Loan-to-Assets \& Loan-to-Deposits).}

$\mathrm{H}_{9}$ is rejected as Figures 9-10 show the conventional bank group was able to maintain less volatile and lower liquidity ratio performance throughout the sample's study period relative to Islamic banks, suggesting more of Islamic banks total assets are tied up in loans as well as more loans being unable to be covered by deposits.

$H_{10}$ : There is a positive relationship between liquidity and the external crisis; this positive relationship is stronger or more apparent in Islamic banks.

$\mathrm{H}_{10}$ is rejected as the Islamic bank group faced a sharp increase and decrease in performance around the identified onset and end of the crisis period, showing a negative relationship between time and liquidity performance - while the conventional group's liquidity performance was little effected by the external crisis.

\section{$H_{11}$ : Conventional banks lead in credit risk (Total Equity to Net Loans).}

$\mathrm{H}_{11}$ is accepted as conventional banks showed higher credit risk performance overall in the study's years relative to Islamic banks in Figure 11 and thus lower credit risk - though with a slight drop in 2011 and thus weakening ability to cover loan losses in the middle of the crisis event and following.

$H_{12}$ : There is a positive relationship between credit risk and the external crisis; this positive relationship is stronger or more apparent in conventional banks.

$\mathrm{H}_{12}$ is accepted for Islamic banks while rejected for conventional banks who showed a negative relationship or drop in credit risk performance during the crisis period, while suggesting nearing convergence of both groups following post-crisis 2012 and after.

\section{Conclusions and Further Research}

This study investigated the impact of the external Arab Spring crisis event on Islamic and conventional bank group's performance in Egypt from 2009 to 2013, through financial ratio analysis of performance indicators reflective of efficiency, capital adequacy, profitability, solvency, liquidity, and credit risk - and whether these then suggest a difference in performance related to differences amid bank models. The results of this analysis broke many preconceived assumptions on the capital breakdown and strategies of both models and the crisis's effect, as revealed in the Discussion. These observed differences in performance were tested for significance through nonparametric tests, in which all ratios except TENL were found to not be statistically significant with $95 \%$ confidence and to have a small effect size. And yet with a small and statistically insignificant sample, the observed ratio trends and differences as continue below replicate conclusions of Fayed (2013), El-Massah and Al-Sayed (2015) among others.

Results of the ratio analysis in the realm of this sample study, referring back to the original question, indicate that regarding efficiency and capital adequacy performance there is no difference between models - while profitability, solvency, liquidity, and credit risk result in an observed difference as further discussed below:

1) Considering efficiency performance, Cost-Income performance is far more volatile and effected by a crisis event than Operational Efficiency - suggesting common challenges as well as responses to maintaining efficiency may exist between both bank models.

2) Capital adequacy is a smaller concern for both bank models as both had strategies in place that allowed them to fairly maintain or increase absorption of shock throughout the crisis event.

3) Profitability is significantly impacted by crisis events for both bank models, but especially an area of concern for Islamic banks - who should consider policies or financial instruments that may decrease volatility or curb losses.

4) Solvency is significantly impacted by crisis events for both bank models, but especially an area of concern for 
Islamic banks pre-crisis - and should rebalance leverage or limit the use of debt financing in times of shock.

5) Liquidity is a larger concern for Islamic banks during a crisis event whereas conventional banks have strategies or less reliance on loans during the course of the crisis that allow them to better withstand liquidity needs during a crisis.

6) Credit risk is a larger concern for conventional banks in the face of a crisis event while Islamic banks are able to decrease this risk - and so conventional banks should consider possible credit or loan limits or other such precautions in times of crisis. Since this performance starts to converge post-crisis, it also suggests growing convergence in practices between models in managing credit risk.

These observed similarities and differences in performance between models implicate the need to further study these trends in order to curb observed performance volatilities and recognize best practices across models amidst or in anticipation of crisis events of similar political nature or beyond - to the benefit of regulators, managers, and investors alike. In the future, continuing this study on a larger scale or diverse sample outside of Egypt relative to an event may be considered to see the effect on bank model performance as well as on earning statistically significant results. This study was limited to bank data available on FactSet, while identifiable resources available with more funding include BankScope and The Banker which can increase the sample as well as time frame investigated. A deeper look at whether the Islamic banks looked at in this study are purely PLS or not and what type of financial instruments they offer may also be considered in future studies, and how this may explain their performance relative to the Arab Spring and to conventional banks. This may also lead into discussion of banking regulations or policies across firms and creating a shared best practices list for such times of crisis.

\section{References}

Almanaseer, M. (2014). The Impact of the Financial Crisis on the Islamic Banks Profitability - Evidence from GCC. International Journal of Financial Research, 5(3).

Arab Spring. Retrieved from https://www.merriam-webster.com/dictionary/ArabSpring

Buse, L., Ganea, M., \& Circiumaru, D. (2010). Using Linear Regression in the Analysis of Financial-Economic Performances. Annals of University of Craiova - Economic Sciences Series, 2(38), 1-12.

Cohen, J. (1988). Statistical Power Analysis for the Behavioral Sciences (2nd ed.). New York: Academic Press.

Corder, G. W., \& Foreman, D. I. (2014). Nonparametric statistics: A step-by-step approach, May: 1-3, 70-73. ProQuest Ebook Central. Retrieved from http://ebookcentral.proquest.com/lib/bryant/detail.action?docID=1676115.

El Massah, S., \& Al Sayed, O. A. (2015). Banking sector performance: Islamic and conventional banks in the UAE. International Journal of Information Technology and Business Management, 36, 69-81.

Elsiefy, E. (2013). Comparative Analysis of Qatari Islamic Banks Performance versus Conventional Banks Before, During and After the Financial Crisis. International Journal of Business and Commerce, 3(3).

Fayed, M. E. (2013). Comparative Performance Study of Conventional and Islamic Banking in Egypt. Journal of Applied Finance \& Banking, 3(2).

Hassan, M. K., \& Bashir, A-H. M. (2005, May). Determinants of Islamic Banking Profitability. Islamic Perspectives on Wealth Creation, 118-40.

Hassan, M. K., \& Lewis, M. (2007). Handbook of Islamic banking. Cheltenham, UK; Northampton, MA, USA: Edward Elgar Publishing, Inc.

Ibrahim, A. J. (2016). Empirical findings on the profitability of banks in Qatar: Islamic vs conventional. International Journal of Business and Commerce, 5(4), 63-78.

Lewis, M. K. (2010). In What Ways Does Islamic Banking Differ from Conventional Finance?. CFA Digest, 40(1), 83-84.

Lim, S. (2019, April 24). Islamic Banking. Retrieved from https://www.investopedia.com/terms/i/islamicbanking.asp

Visser, H. (2013). Islamic Finance: Principles and Practice (7th ed.). Cheltenham, UK; Northampton, MA, USA: Edward Elgar Publishing, Inc.

Yahya, A. T., Akhtar, A., \& Tabash, M. I. (2017). The impact of political instability, macroeconomic and bank-specific factors on the profitability of Islamic banks. Investment Management and Financial Innovations, 14(4), 30-39. 
Appendix A. Critical Values for the Mann-Whitney U-Test

Level of significance: $5 \%(\mathrm{P}=0.05)$

Size of the largest sample (nz)

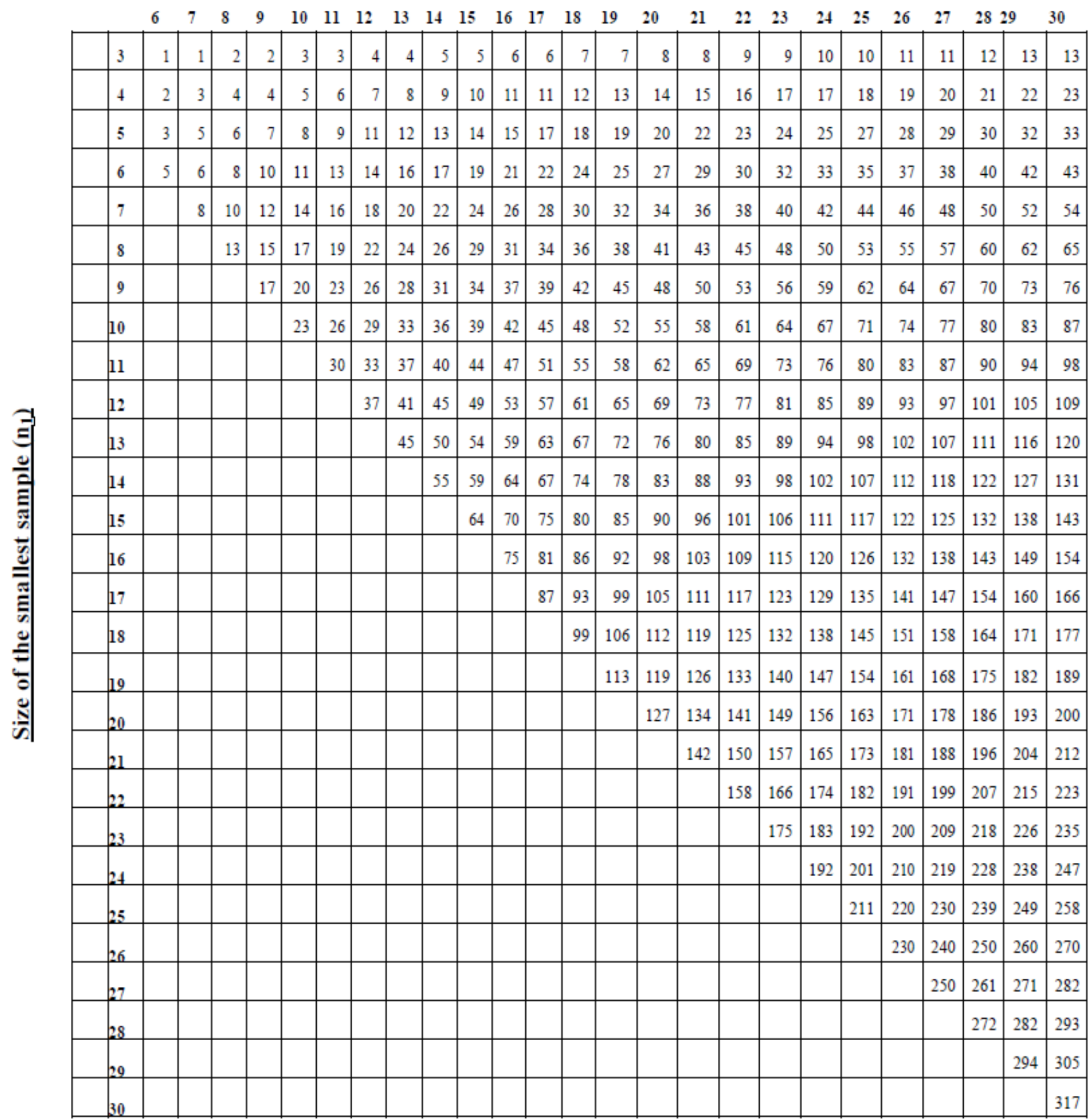

